\title{
Microbiological profile and aerobic stability of Tifton 85 bermudagrass silage with different additives
}

\author{
Marcela Abbado Neres ${ }^{1}$, Maximiliane Alavarse Zambom ${ }^{1}$, Tatiane Fernandes ${ }^{2}$, Deise Dalazen \\ Castagnara ${ }^{1}$, Juliana Ferraz Huback Rodrigues ${ }^{1}$, Loreno Egidio Taffarel ${ }^{2}$, Cleovani Rossi \\ Javorski ${ }^{2}$, Magali Soares dos Santos Pozza ${ }^{1}$
}

\footnotetext{
${ }^{1}$ Centro de Ciências Agrárias - Unioeste PR. Rua Pernambuco, 1777, Centro, CEP 85960-000, Marechal Cândido Rondon, PR, Brazil.

${ }^{2}$ Mestrandos do Programa de Pós-Graduação em Zootecnia da Unioeste - PR, Brazil.
}

\begin{abstract}
The objective of this study was to evaluate the microbiological profile and aerobic stability of silage with Tifton 85 bermudagrass and different additives and wilting. The studied treatments were: pre-drying in the sun for two hours before ensiling; use of bacterial-enzymatic inoculant; addition of soybean peel; addition of corn grits and use of salt in the surface layer of the silo. The experimental design was completely randomized with six treatments and four replications. Plants of Tifton 85 bermudagrass with 38 days were ensiled in experimental silos with Bunsen valves, with compacting density of $236 \mathrm{~kg}$ silage per $\mathrm{m}^{3}$ for Tifton 85 bermudagrass, which was pre-dried in the sun; the average silage was $294 \mathrm{~kg} \mathrm{~m}^{-3}$ for the other treatments. The ratios between soybean hulls and corn grits, added to the silage, were calculated based on the initial DM content from Tifton 85 bermudagrass in order to obtain $320 \mathrm{~g} / \mathrm{kg} \mathrm{DM}$ of the material to be ensiled. There was an increase of lactic bacteria and Clostridium as well as an absence of enterobacteria after the silo opening. Fungi developed only in Tifton 85 bermudagrass and its treatments before the ensilage and yeasts developed in silages of Tifton 85 bermudagrass when they received soybean hulls or corn grits after silo opening. There was no breach regarding aerobic stability of silages during the studied period. The $\mathrm{pH}$ reached the highest values within 48 hours after opening the silos, but there were variations during this period.
\end{abstract}

Key Words: Clostridium, enterobacteria, $\mathrm{pH}$ silage, temperature silage, yeasts

\section{Introduction}

The ensiling process is complex due to the large number of microorganisms involved. It can be considered a metabiosis since there is a simultaneous and successive development of microorganisms with different genders and species, which depend mainly on $\mathrm{pH}$, redox potential and the kind and amount of substrate in the environment (Pereira \& Santos, 2006).

The silo opening and silage removal to feed animals promote environmental aeration. Thus, this management allows for the yeast activity on oxidizing organic acids, preserving the silage and triggering aerobic degradation, thus causing an increase in $\mathrm{pH}$ and temperature, which then favors fungal growth.

The silages with greater susceptibility to aerobic deterioration are rich in soluble carbohydrates and starch such as the ones from corn or those in which fermentation was restricted by the use of additives and/or by the excessive wilting of forage before ensilage (Castro et al., 2006). Homofermentative microorganisms are characterized by a faster fermentation rate, reduced proteolysis, higher concentration of lactic acid and higher restoration of energy and dry matter. On the other hand, the acetic and propionic acids produced by heterofermentative bacteria are more effective in controlling fungi and yeasts. The control of clostridia development depends on $\mathrm{pH}$ decrease and osmotic pressure increase (Woolford, 1984).

The plastic sheeting usually used in sealing silos (made of polyethylene film) has shown high permeability to oxygen and can facilitate aerobic deterioration of the silage, so there is a disposal of these silage portions. In order to avoid these losses, some producers have adopted a common practice of using salt on the upper layer of the silo. Therefore, further studies on the effects of such practice on the microbiological profile of what remains from this silage are essential.

Many authors have pointed out that when temperature increases by $1{ }^{\circ} \mathrm{C}$ and silage gets in contact with oxygen after opening the silos, this can mean a breach in aerobic stability (Driehuis et al., 2001). Because of the importance of information about aerobic stability of Tifton 85 bermudagrass silages under different treatments, this experiment was carried out to evaluate the $\mathrm{pH}$, temperature 
and microbiological profile of Tifton 85 bermudagrass silage and its association with soybean hulls or corn grits. The addition of bacterial-enzymatic additive and the sun wilting process were also evaluated.

\section{Material and Methods}

This trial was carried out at Universidade Estadual do Oeste Paraná - Campus Marechal Cândido Rondon - PR, Brazil, whose geographic coordinates are: $24^{\circ} 19^{\prime} \mathrm{S}$ latitude, $54^{\circ} 01^{\prime} \mathrm{W}$ longitude and $392 \mathrm{~m}$ altitude. The local weather is classified according to Köppen as subtropical Cfa, with well distributed rainfall during the year and hot summers. The coldest trimester recorded temperatures between 17 and $18^{\circ} \mathrm{C}$, while the hottest one showed ranges from 28 to $29^{\circ} \mathrm{C}$, so the annual temperature ranged from 22 to $23{ }^{\circ} \mathrm{C}$.

The total normal average of pluvial precipitation per year for this region ranges from 1600 to $1800 \mathrm{~mm}$. The most humid trimester showed total ranges from 400 to $500 \mathrm{~mm}$ and the driest one recorded data between 250 and $350 \mathrm{~mm}$ (IAPAR, 2006). The soil of this region is classified as an eutroferric Red Latosol with loamy texture (EMBRAPA, 2006) and the following chemical characteristics: $\mathrm{pH}$ in water - 5.05; P (Mehlich) - $17.44 \mathrm{mg} / \mathrm{dm}^{3}$; $\mathrm{K}$ (Mehlich) $0.47 \mathrm{cmol}_{\mathrm{c}} / \mathrm{dm}^{3} ; \mathrm{Ca}^{2+}\left(\mathrm{KCl} 1 \mathrm{~mol} . \mathrm{L}^{-1}\right)-4.39 \mathrm{cmol}_{\mathrm{c}} / \mathrm{dm}^{3}$; $\mathrm{Mg}^{2+}(\mathrm{KCl} 1 \mathrm{~mol} / \mathrm{L})-2.63 \mathrm{cmol}_{\mathrm{c}} / \mathrm{dm}^{3} ; \mathrm{Al}^{3+}(\mathrm{KCl} 1 \mathrm{~mol} / \mathrm{L})$ - $0.00 \mathrm{cmol}_{\mathrm{c}} / \mathrm{dm}^{3} ; \mathrm{H}+\mathrm{Al}$ (calcium acetate $0.5 \mathrm{~mol} / \mathrm{L}$ ) $3.84 \mathrm{cmol}_{\mathrm{c}} / \mathrm{dm}^{3}$; base saturation $-7.49 \mathrm{cmol}_{\mathrm{c}} / \mathrm{dm}^{3}$; cation exchange capacity $-11.33 \mathrm{cmol}_{\mathrm{c}} / \mathrm{dm}^{3} ; \mathrm{V}-66.11 \%$; organic matter (Boyocus method) - $23.92 \mathrm{~g} / \mathrm{dm}^{3}$ and clay - $65 \%$.

The experimental design was completely randomized with six treatments and four replications. Treatments were Tifton 85 bermudagrass silage without additives; Tifton 85 bermudagrass silage with addition of soybean hulls, corn grits or inoculants; Tifton 85 bermudagrass silage pre-dried in the sun; and Tifton 85 bermudagrass silage with kosher salt on the top layer.

The area was used to cut grass and for ensilage of Tifton 85 bermudagrass was a hay field from the Experimental Farm from Universidade Estadual do Oeste Paraná. When the grass was at 38 days of vegetative development and $20 \mathrm{~cm}$ in height, on May 16th, 2011, Tifton 85 bermudagrass was harvested at $5 \mathrm{~cm}$ from the soil and a shredder was used to chop it to an average $3 \mathrm{~cm}$ length.

Tifton 85 bermudagrass dry matter content $(250 \mathrm{~g} / \mathrm{kg})$ was determined by the use a forced-ventilation oven at $60{ }^{\circ} \mathrm{C}$ three days before the ensilage. The amount of soybean hulls or corn grits was calculated $(120 \mathrm{~g} / \mathrm{kg})$ to obtain silage dry matter $(\mathrm{DM})$ content $(320 \mathrm{~g} / \mathrm{kg})$. In the treatment of pre-drying in the sun, the grass was chopped and kept in the sun for two hours for dehydration so that its DM content reached $319.9 \mathrm{~g} / \mathrm{kg}$.

The dry matter contents obtained in Tifton 85 bermudagrass and its treatments after mixtures were: $286.0 \mathrm{~g} / \mathrm{kg}$ in the control, $329.3 \mathrm{~g} / \mathrm{kg}$ with corn grits, $347.4 \mathrm{~g} / \mathrm{kg}$ with soybean hulls, $280.5 \mathrm{~g} / \mathrm{kg}$ with inoculant and $285.4 \mathrm{~g} / \mathrm{kg}$ with kosher salt $(20 \mathrm{~kg}$ of silage were prepared for each treatment).

The inoculant (Lacto silo Gold ${ }^{\circledR}$-Nitral Urbana) presented the following levels guaranteed: $1.0 \times 10^{9}$ colony-forming units $(\mathrm{cfu} / \mathrm{g})$ of: Lactobacillus curvatus, L. acidophilus, L. plantarum, L. buchineri, Pedicoccus acidilactici, Enterococcus faecium, Lactococcus lactis and $85 \mathrm{u} / \mathrm{g}$ Cellulase. The dilutions were: $43 \mathrm{~g}$ of inoculant in $10 \mathrm{~L}$ of free chlorine water at room temperature. The proportion of $200 \mathrm{~mL}$ per $100 \mathrm{~kg}$ of silage was applied with with a backpack sprayer.

The experimental PVC silos were $10 \mathrm{~cm}$ in diameter and $50 \mathrm{~cm}$ in high, with covers with Bunsen valves. A $5 \mathrm{~cm}$ layer of autoclaved and dried sand was put at the bottom of the silo and separated from the silage by cotton fabric to allow a possible flow of the effluent produced. Then, $2.06 \mathrm{~kg}$ of silage per silo were conditioned at an equivalent density of $294 \mathrm{~kg} \mathrm{~m}^{-3}$ silage. In the pre-drying treatment, density was lower with $1.89 \mathrm{~kg}$ silage per silo, corresponding to $236 \mathrm{~kg} \mathrm{~m}^{-3}$ density of silage. The silos were kept in a protected place at room temperature.

During the pre-drying of Tifton 85 bermudagrass, the climate data were: air temperature $\left({ }^{\circ} \mathrm{C}\right)$ : average - 15.9; maximum - 23.1; minimum - 10.1. Relative air humidity (\%): average - 80.3; maximum - 98.0; minimum - 50.0. Atmospheric pressure $(\mathrm{kPa})$ : average - 970.9; maximum 972.5; minimum - 969.9. Wind (m/s): speed -2.5 and gust of wind - 7.8; Radiation $\left(\mathrm{KJ} / \mathrm{m}^{2}\right): 17379.100$ and rain $(\mathrm{mm}): 0.0$.

Samples of fungi and bacteria were collected before and after 30 days of ensilage, but yeast samples were obtained only after opening silos. After 30 days, the silos were weighed then opened. A $5 \mathrm{~cm}$ layer of the top and another $5 \mathrm{~cm}$ layer of the bottom of each silo were removed and the remainders of the silage were homogenized.

Thereafter, $\mathrm{pH}$ was determined by a potentiometer in the aqueous extract formed by a fraction of $25 \mathrm{~g}$ of sample mixed to $450 \mathrm{~mL}$ deionized water, according to the methodology described by Cherney \& Cherney (2003). Silage temperature was recorded with a digital skewer thermometer. A second portion $(50 \mathrm{~g})$ was taken to microbiological analysis at the Microbiology Laboratory, UNIOESTE.

The possible microbial changes and the most important populations in the fermentation process of silages were 
determined by selective culture techniques: $450 \mathrm{~mL}$ of distilled water were added to $50 \mathrm{~g}$ samples and from the solution obtained $1 \mathrm{~mL}$ was pipetted with dilutions ranging from $10^{2}$ to $10^{9}$. Bottles were used for water dilution with $99.9 \mathrm{~mL}$ buffer solution.

Microbial populations from both original and ensiled material were determined by culture techniques according to Silva et al. (1997) using the following mediums: Potato Dextrose Agar to count filamentous fungus; Lactobacillus MRS Broth to count Lactobacillus with plates kept under incubation at $35{ }^{\circ} \mathrm{C}$ for 72 hours; Violet Red Bile Agar (Oxford) to enterobacterial count with plates kept under incubation at $35{ }^{\circ} \mathrm{C}$ for 72 hours; Reinforced Clostridial Agar to count clostridia with plates kept in anaerobic incubation utilizing jars with gas system - Park at $35^{\circ} \mathrm{C}$ for 72 hours.

After the incubation period, the colonies were counted by a Quebec colony counter. The plates between 30 and 300 cfu (Colony Forming Unit) were counted in a Petri plate and the results were obtained by an average of plates, expressed by log.

The yeasts were isolated by growth induction in YEPG culture medium environment (yeast extract, peptone, glucose, Agar and water). Samples were collected at the opening of silos on the 3rd, 5th and 7th days after their exposure to an aerobic environment. Three days after the inoculation, the count of Petri plates was carried out and plastes were kept in BOD for 72 hours at $28^{\circ} \mathrm{C}$.

Fungi were isolated by induction of mycelium growth in BDA culture medium by induced sporulation or direct isolation of signals (reproductive structures) of pathogen according to the collected samples (Fernandez, 1993; Menezes \& Silva-Hanlin, 1997).

According to the stereoscopic microscopic (magnifying glass) observation, semi-permanent blades were prepared to record all fungal structures in both symptomatic material and in culture medium. Those structures were transferred with a needle or stiletto for a microscope slide with lactophenol cotton blue staining, covered with cover slip, sealed with glaze and observed on an optical microscope to identify each fungus, with specific key-identification aid (Barnett \& Hunter, 1987; Carmichael et al., 1980; Guarro et al., 1999; Samson et al., 1995).

A part of the silage was used to study its aerobic stability. Two samples of $300 \mathrm{~g}$ (one portion to measure temperature and another to collect samples, determine $\mathrm{pH}$ and count yeasts and fungi) were conditioned in plastic trays during seven days (at $08 \mathrm{~h} 00$ and 17h00). Silage and air temperatures as well as $\mathrm{pH}$ were measured. The $\mathrm{pH}$ was determined with a potentiometer, according to the methodology described by Cherney \& Cherney (2003) and the silage temperature with a digital skewer thermometer. The increase of $1{ }^{\circ} \mathrm{C}$ above room temperature was considered a breach of aerobic stability (Driehuis et al., 2001).

The obtained data were subjected to statistical analysis on the software SAEG (Sistema para Análises Estatísticas e Genéticas, version 8.0) and the treatments were compared by the Tukey test at $5 \%$ probability level.

\section{Results and Discussion}

Before the ensilage, the highest occurrence of enterobacteria was observed when a microbial inoculant and soybean hulls were added to Tifton 85 bermudagrass $(\mathrm{P}<0.05)$, while the lowest occurrence of enterobacteria was obtained with the addition of corn grits (Table 1). However, the total population of enterobacteria was superior to the lactic bacteria. This is coherent with Pereira \& Santos (2006), who stated that epiphytic population of enterobacteria can almost always reach superior values to lactic bacteria.

Clostridium population was superior when Tifton 85 bermudagrass was mixed with soybean hulls and when it was pre-dried in the sun (Table 1). According to Pahlow et al. (2003), the use of wilting technique to increase forage dry matter can increase Clostridium spores in the silage because it retards $\mathrm{pH}$ decrease, in which, under favorable conditions, they can be developed.

Table 1 - Occurrence of bacteria (log $\mathrm{cfu} / \mathrm{g})$ in Tifton 85 bermudagrass additives before ensilage

\begin{tabular}{|c|c|c|c|c|}
\hline & Enterobacteria & Clostridium & Lactic acid bacteria & Total \\
\hline Tifton 85 & $4.320 \mathrm{~b}$ & $2.865 \mathrm{c}$ & $3.070 \mathrm{~b}$ & $5.190 \mathrm{~b}$ \\
\hline Tifton $85+$ corn grits & $2.265 \mathrm{e}$ & $2.920 \mathrm{c}$ & $2.340 \mathrm{e}$ & $5.125 \mathrm{~b}$ \\
\hline Tifton $85+$ soybean hulls & $4.745 \mathrm{a}$ & $3.565 \mathrm{a}$ & $2.775 \mathrm{~d}$ & $5.780 \mathrm{a}$ \\
\hline Tifton $85+$ inoculant & $4.810 \mathrm{a}$ & $3.000 \mathrm{c}$ & $2.880 \mathrm{c}$ & $5.720 \mathrm{a}$ \\
\hline Tifton $85+$ sun & $4.015 \mathrm{c}$ & $3.590 \mathrm{a}$ & $2.885 \mathrm{c}$ & $4.825 \mathrm{c}$ \\
\hline Tifton $85+$ salt & $3.040 \mathrm{~d}$ & $3.205 b$ & $3.265 \mathrm{a}$ & $5.055 b$ \\
\hline Mean & 3.866 & 3.191 & 2.869 & 5.283 \\
\hline CV (\%) & 2.27 & 1.75 & 1.08 & 0.99 \\
\hline
\end{tabular}

Sun - pre-drying in the sun; Salt - salt on top of silage; ns - not significant; CV - coefficient of variation.

Means followed by the same letter in the column do not differ by the Tukey test $(5 \%)$. 
Although the bacterial-enzymatic additive presents Lactobacillus colonies, the treatment Tifton 85 bermudagrass with microbial additive showed a bacterial count that was similar to the ones of plants pre-dried in the sun (Table 1).The treatments Tifton 85 bermudagrass + salt and Tifton 85 bermudagrass without additives showed higher count of lactic bacteria. Those analyses of count were performed in $10^{2} \mathrm{cfu} / \mathrm{g}$ silage dilution, whose initial microflora was low.

Meeske et al. (1999) also found a low population of Lactobacillus: nearly $101 \mathrm{cfu} / \mathrm{g}$ of fresh forage in Digitaria eriantha plants. Even with a low count, the population showed an increase at opening of silos, probably due to the presence of factors favorable to such growth. At the beginning of the ensilage process, aerobic microorganisms and facultative anaerobic bacteria can be developed at higher $\mathrm{pH}$ and also predominate in such medium. As $\mathrm{pH}$ decreases and oxygen is consumed (aerobic microorganisms and plants breathing process), anaerobic and facultative anaerobic bacteria that are tolerant to acidity such as lactic acid bacteria (LAB) replace the previous ones (Pahlow et al., 2003).

The total bacterial population followed a similar pattern to the one observed for enterobacteria, with a superior incidence in Tifton 85 bermudagrass with addition of soybean hulls and microbial inoculant.

After the ensilage, no enterobacteria development was observed (Table 2). Pereira et al. (2007) did not record this kind of bacteria group from the 7th to the 28th day of fermentation in silages of elephant grass treated with bacterial-enzymatic inoculant and the same was observed by Bernardes et al. (2005), who did not detect presence of microorganisms in silages of Brachiaria brizantha with addition of pelletized citrus pulp from the 4th day. The population of lactic acid bacteria was constant in all studied treatments, but at total count, it was found that during the pre-drying in the sun, there was a higher development of microorganisms (Table 1).

There was an increase in the populations of both Clostridium and lactic bacteria after the opening silos (Table 2). The presence of Clostridium in silage is not desirable since, depending on the species, it can ferment carbohydrates and proteins or both, reducing the nutritional value of silage and in addition reducing silage intake by animals. When silages were pre-dried in the sun and received corn grits and soybean hulls, the dry matter contents were over $300 \mathrm{~g} / \mathrm{kg}$ and the others were around $280 \mathrm{~g} / \mathrm{kg}$ $\mathrm{DM}$, recommended for inhibiting the development of clostridia. Thus, this would not justify the increase in bacteria of Clostridium gender; a factor that should be better studied in the future experiments with tropical grasses silages.

Jobim et al. (1999) evaluated the development of microorganisms in silages with moist corn grits and corn cobs and observed a lower development of Clostridium ( 0.1 and $0.2 \mathrm{cfu} / \mathrm{g}$ silage, for moist grit and cob, respectively) as well as high development of Lactobacillus (8.3 and $8.9 \mathrm{cfu} / \mathrm{g}$ silage for the same treatments). On the other hand, Tosi et al. (1999) obtained $3.55 \mathrm{cfu} / \mathrm{g}$ silages of clostridia in pre-dried silages of Taiwan elephant grass.

Fungi were present in tifton 85 bermudagrass with those pre-treatments, but the genera Phoma and Cladosporium (typical field fungus) were the highest occurrence. In Brazil, although Tifton 85 bermudagrass does not show visible symptoms of leaf spot, Anjos et al. (2005) reported cases of leaf spot in Paspalum atratum cv. Pojuca due to presence of fungus of the genus Phoma. These authors also verified susceptibility in $B$. decumbens and corn plants to the same fungus. It is worh remarking that in the studied region corn crop and off-season corn crop as well as soybean crops are produced in large areas, so the presence of this fungus genus in pastures areas should be evaluated and researched with strict criteria, due to the possible pathogenicity of this fungus on plants of tifton 85 bermudagrass.

In the silage pre-dried in the sun, the incidence of Cladosporium and Risophus was lower $(\mathrm{P}<0.05)$ when compared with the other treatments (Table 3). Fungi such as Penicillium, Aspergillus and Risophus were seldom observed with a count performed at $10^{1} \mathrm{cfu} / \mathrm{g}$ silage dilution for all genera.

Table 2 - Occurrence of bacteria (log $\mathrm{cfu} / \mathrm{g})$ in Tifton 85 bermudagrass silage

\begin{tabular}{lcccc}
\hline & Enterobacteria & Clostridium & Lactic acid bacteria & Total \\
\hline Tifton 85 & $0.000 \mathrm{~ns}$ & $6.485 \mathrm{~ns}$ & $4.583 \mathrm{~ns}$ & $6.403 \mathrm{c}$ \\
Tifton 85 + corn grits & 0.000 & 6.545 & 3.903 & $6.388 \mathrm{c}$ \\
Tifton 85 + soybean hulls & 0.000 & 6.845 & 4.308 & $7.185 \mathrm{ab}$ \\
Tifton 85 + inoculant & 0.000 & 6.398 & 4.698 & $6.913 \mathrm{abc}$ \\
Tifton 85 + sun & 0.000 & 6.995 & 4.635 & $7.478 \mathrm{a}$ \\
Tifton 85 + salt & 0.000 & 6.858 & 4.220 & $6.638 \mathrm{bc}$ \\
Mean & 0.000 & 7.004 & 4.391 & 6.834 \\
CV $(\%)$ & 0.00 & 4.74 & 9.73 & 4.06 \\
\hline
\end{tabular}

Sun - pre-drying in the sun; Salt - salt on top of silage; ns - not significant; CV - coefficient of variation.

Means followed by the same letter in the column do not differ by the Tukey test $(5 \%)$. 
The genera Penicillium and Aspergillus were the most particular concerns due to production of mycotoxin and aflatoxin, whcih cause real hazard to the animal health and are transferred to the milk of lactating cows. These mycotoxins are not inactivated by pasteurization of milk; therefore, today they are a major health concern in the use of both silage and hay for animal feeding. However, after opening silos, the emergence of fungi was occasional and did not reach the minimum count of $30 \mathrm{cfu} / \mathrm{g}$ silage in the studied dilutions. Fungi are aerobic and normally appear in large amounts in a period of aerobic deterioration, mostly after growth of yeasts and aerobic bacteria (McDonald et al., 1991).

There was no breach of aerobic stability during the seven days of exposure to the air in this trial, which may have contributed to a good silage preservation and inhibition of their growth. Castro et al. (2006) evaluated the microbiological profile of silages of Tifton 85 bermudagrass with different dry matter concentrations and application of additives and observed sporadic colonies of Aspergillus sp, Penicillium $\mathrm{sp}$ in the initial sampling and absence in the other storage periods (32 and 180 days). Schocken-Iturrino et al (2005) evaluated the presence of fungi in Tifton 85 bermudagrass silages with wilting and citrus pulp and observed low aerobic stability and an increase in occurrence of Penicillium, Fusarium and Phitomyces as they were more exposed to air.

The microbiological analyses of Tifton 85 bermudagrass and the mixtures which were ensiled showed no development of yeast at times 0 and 1 . The anaerobic conditions and organic acids concentration are two factors that affect yeast survival during silage storage (Bravo-Martins et al., 2006), provided by the presence of oxygen into a silo (Jonsson \& Pahlow, 1984).

Yeasts are able to develop at low concentrations of oxygen (McDonald et al., 1991) and in a wide $\mathrm{pH}$ range (3 to 8) (Lima et al., 2002). According to Woolford (1990), yeasts are also able to ferment other sugars besides glucose. They have an extra source of energy in order to bear adverse effects of low $\mathrm{pH}$ and anaerobic conditions of a silo.
On the third day after opening silos, regarding the treatment with soybean hulls and corn grits, there was yeast growth and such response differed $(\mathrm{P}<0.05)$ from the other treatments (Figure 1). Five days after the silo opening, in addition to the treatments with soybean hulls and corn grits for Tifton 85 bermudagrass without additives, some yeast growth was also observed. Within a week after opening the silos, only the treatments with soybean hulls and corn grits provided some yeast growth (Figure 1). Woolford (1990) considers that silages with yeast count above $5.0 \log \mathrm{cfu} / \mathrm{g}$ of silage are highly susceptible to deterioration.

The results obtained in silages with corn grits and soybean hulls are in agreement with Berger \& Bolsen (2006), who recommended higher rates of silo unloading to prevent silage deterioration with presence of grits.

It was observed that the highest $\mathrm{pH}$ reponse occurred 48 hours after opening the silos (Table 4), but this was

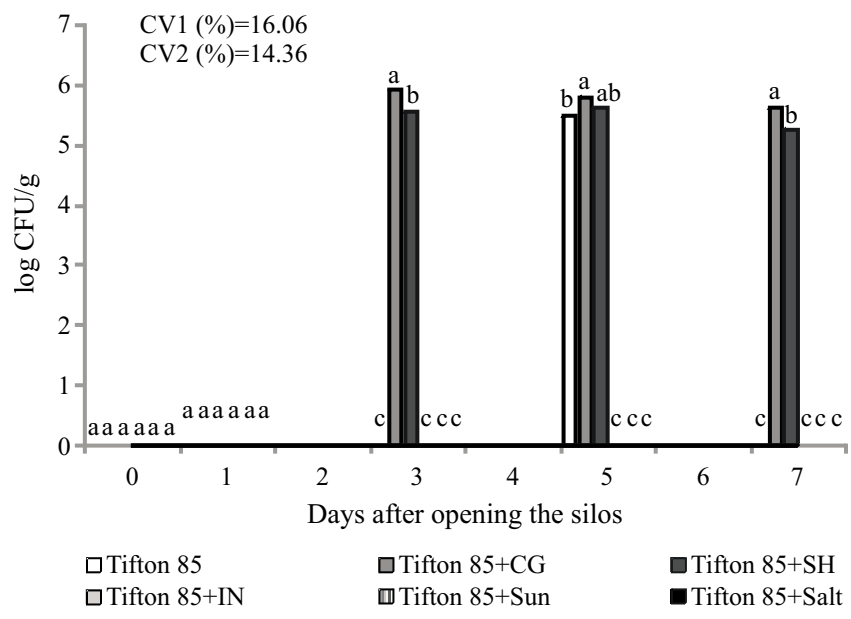

$\mathrm{CV}$ - coefficient of variation; CG - corn grits; $\mathrm{SH}$ - soybean hulls; IN - inoculant Sun - pre-drying in the sun; Salt - salt on the top of silos.

Bars followed by the same letter do not differ by the Tukey test $(5 \%)$.

Figure 1 - Yeast growth in Tifton 85 bermudagrass silage with different additives during 168 hours after the opening of silos.

Table 3 - Fungi occurrence (log cfu/g) in Tifton 85 bermudagrass with additives and pre-drying before ensilage

\begin{tabular}{lcccccc}
\hline Treatments & Cladosporium & Penicillium & Risophus & Aspergillus & Phoma & Total \\
\hline Tifton 85 & $3.86 \mathrm{a}$ & $0.00 \mathrm{~b}$ & $2.15 \mathrm{a}$ & $2.39 \mathrm{~ns}$ & $4.31 \mathrm{a}$ & $4.46 \mathrm{a}$ \\
Tifton 85 + corn grits & $3.35 \mathrm{a}$ & $1.11 \mathrm{~b}$ & $1.00 \mathrm{ab}$ & 2.49 & $3.77 \mathrm{~b}$ & $4.32 \mathrm{ab}$ \\
Tifton 85 + soybean hulls & $3.63 \mathrm{a}$ & $0.00 \mathrm{~b}$ & $2.30 \mathrm{a}$ & 1.15 & $4.36 \mathrm{a}$ & $4.46 \mathrm{a}$ \\
Tifton 85 + inoculate & $3.08 \mathrm{a}$ & $0.00 \mathrm{~b}$ & $2.15 \mathrm{a}$ & 2.00 & $4.40 \mathrm{a}$ & $4.43 \mathrm{a}$ \\
Tifton 85 + sun & $1.00 \mathrm{~b}$ & $2.89 \mathrm{a}$ & $0.00 \mathrm{~b}$ & 1.00 & $4.49 \mathrm{a}$ & $4.32 \mathrm{ab}$ \\
Tifton 85 + salt & $3.59 \mathrm{a}$ & $0.00 \mathrm{~b}$ & $1.00 \mathrm{ab}$ & 2.00 & $4.17 \mathrm{~b}$ & 4.18 \\
Mean & 3.08 & 0.67 & 1.43 & 1.84 & 3.58 & 1.27 \\
CV $(\%)$ & 14.61 & 28.75 & 31.62 & 33.90 & & 3.58 \\
\hline
\end{tabular}

Sun - pre-drying in the sun; Salt - salt on top of silage; ns - not significant; CV - coefficient of variation.

Means followed by the same letter in the column do not differ by the Tukey test $(5 \%)$. 
not reflected at the moment of aerobic stability breaching because the room temperature was higher than silage temperature. The final $\mathrm{pH}$ was the lowest response after seven days of aerobic exposition and occurred in the tifton 85 bermudagrass silage without treatments and in the silage with bacterial-enzymatic inoculant. These $\mathrm{pH}$ responses did not differ from the initial $\mathrm{pH}$ of these treatments (Table 4).

According to Cherney \& Cherney (2003), pH still remains as a good indicator of fermentation quality in silages with low DM content and is not viable for silages with high DM content. The increase in contents of dry matter is required in silage conservation, since the decrease in water activity (Wa) can have an additional effect on the pH decrease (Lindgren, 1999).

There was no significant difference among the treatments for the temperature values of silages at all studied times (Table 5). The temperature values obtained allow us to infer that there was no deterioration in produced silages and they present high aerobic stability, because in practice, silage deterioration is usually manifested by an increase in temperature (Castro et al., 2006). It still changes a lot in relation to the types of ensiled forages (McDonald et al., 1991). Bernardes (2006) observed some increases in $\mathrm{pH}$ from the first to the third day of aerobic exposition of Marandugrass silages and these values remained stable after 6 days of air exposure, and the temperature did not exceed $2{ }^{\circ} \mathrm{C}$ at room temperature $\left(25^{\circ} \mathrm{C}\right)$.

The silage aerobic deterioration is unwanted because of nutrient loss, low feeding by animals (McDonald et al., 1991) and likely increased proliferation risk of potential pathogenic or undesirable microorganisms (Driehuis et al., 2001).The silages that present highest susceptibility to aerobic deterioration are those in which fermentation was restricted by the use of additives and/or excessive wilting before ensilage (Castro et al., 2006).

Bernardes et al. (2005) reported that silages of tropical grasses with less than $30 \%$ dry matter present, during aerobic exposition, greater development of Bacillus and enterobacteria because of $\mathrm{pH}$ above 4.5 , humidity and lack of substrates for fungi and yeasts. Muck (2004) also states

Table 4 - Values of $\mathrm{pH}$ and temperature of Tifton 85 bermudagrass silages during 7 days of aerobic stability evaluation

\begin{tabular}{|c|c|c|c|c|c|c|}
\hline \multirow{2}{*}{ Treatments } & \multicolumn{3}{|c|}{$\mathrm{pH}$} & \multirow{2}{*}{$\begin{array}{c}\text { Time } \\
\text { (hours) }^{1}\end{array}$} & \multirow{2}{*}{$\begin{array}{l}\text { Room temperature } \\
\qquad\left({ }^{\circ} \mathrm{C}\right)^{1}\end{array}$} & \multirow{2}{*}{$\begin{array}{l}\text { Silage temperature } \\
\qquad\left({ }^{\circ} \mathrm{C}\right)^{1}\end{array}$} \\
\hline & Initial & Final & Maximum & & & \\
\hline Tifton 85 & $4.00 \mathrm{~b}$ & $4.00 \mathrm{~b}$ & $5.00 \mathrm{a}$ & 48 & 23.6 & $22.00 \mathrm{~ns}$ \\
\hline Tifton $85+$ corn grits & $4.00 \mathrm{~b}$ & $4.50 \mathrm{ab}$ & $5.00 \mathrm{a}$ & 48 & 23.6 & 23.50 \\
\hline Tifton $85+$ soybean hulls & $4.15 b$ & $4.56 \mathrm{ab}$ & $5.00 \mathrm{a}$ & 48 & 23.6 & 23.68 \\
\hline Tifton $85+$ inoculant & $4.00 \mathrm{~b}$ & $4.35 b$ & $5.00 \mathrm{a}$ & 48 & 23.6 & 22.03 \\
\hline Tifton $85+$ sun & $4.00 \mathrm{c}$ & $4.84 \mathrm{ab}$ & $4.93 \mathrm{a}$ & 48 & 23.6 & 23.13 \\
\hline Tifton $85+$ salt & $4.00 \mathrm{c}$ & $4.72 \mathrm{ab}$ & $5.00 \mathrm{a}$ & 48 & 23.6 & 23.85 \\
\hline CV $(\%)$ & & 18.8 & & & & 17.18 \\
\hline
\end{tabular}

Sun - pre-drying in the sun; Salt - salt on the top of silage.

Different letters in the same row $(\mathrm{pH})$ and column (temperature) differ by the Tukey test $(5 \%)$.

${ }^{1}$ When reaching maximum $\mathrm{pH}$.

Table 5 - Average temperature of the silages from Tifton 85 bermudagrass 168 hours after opening silos

\begin{tabular}{|c|c|c|c|c|c|c|c|}
\hline \multirow[b]{2}{*}{$\begin{array}{l}\text { Room } \\
\text { temperature }\left({ }^{\circ} \mathrm{C}\right)\end{array}$} & \multirow[b]{2}{*}{ Time (hours) } & \multicolumn{6}{|c|}{ Treatments } \\
\hline & & Tifton 85 & $\begin{array}{c}\text { Tifton } 85+ \\
\text { corn grit }\end{array}$ & $\begin{array}{c}\text { Tifton } 85+ \\
\text { soybean hulls }\end{array}$ & $\begin{array}{l}\text { Tifton } 85+ \\
\text { inoculant }\end{array}$ & $\begin{array}{l}\text { Tifton } 85+ \\
\text { sun }\end{array}$ & $\begin{array}{c}\text { Tifton } 85+ \\
\text { salt }\end{array}$ \\
\hline 20.8 & Ons & 22.75 & 23.48 & 23.25 & 22.23 & 23.45 & 23.28 \\
\hline 26.8 & $7 \mathrm{~ns}$ & 22.50 & 23.43 & 23.50 & 22.48 & 23.40 & 23.33 \\
\hline 21.8 & $24 n s$ & 22.75 & 23.45 & 23.45 & 22.45 & 23.18 & 23.45 \\
\hline 26.9 & $31 \mathrm{~ns}$ & 22.00 & 23.48 & 23.63 & 22.48 & 22.80 & 23.48 \\
\hline 23.6 & $48 \mathrm{~ns}$ & 22.00 & 23.50 & 23.68 & 22.03 & 23.13 & 23.85 \\
\hline 27.6 & $55 \mathrm{~ns}$ & 21.75 & 23.45 & 23.55 & 22.23 & 23.10 & 23.80 \\
\hline 21.9 & $72 \mathrm{~ns}$ & 22.00 & 22.75 & 23.48 & 22.58 & 22.98 & 23.83 \\
\hline 28.3 & $79 \mathrm{~ns}$ & 22.00 & 22.70 & 23.53 & 22.58 & 23.05 & 23.85 \\
\hline 21.8 & $96 \mathrm{~ns}$ & 22.25 & 22.73 & 23.55 & 22.60 & 22.93 & 23.75 \\
\hline 26.3 & $103 \mathrm{~ns}$ & 23.00 & 22.70 & 22.83 & 22.28 & 23.48 & 24.05 \\
\hline 24.6 & $120 \mathrm{~ns}$ & 22.75 & 22.98 & 23.18 & 22.73 & 23.45 & 23.78 \\
\hline 25.6 & $127 \mathrm{~ns}$ & 23.00 & 22.90 & 22.53 & 22.50 & 23.18 & 24.00 \\
\hline 24.4 & $144 \mathrm{~ns}$ & 22.75 & 24.03 & 22.73 & 22.50 & 23.55 & 23.63 \\
\hline 25.6 & $15 \operatorname{lns}$ & 22.75 & 23.53 & 22.90 & 22.25 & 23.40 & 24.00 \\
\hline 27.6 & $168 \mathrm{~ns}$ & 23.00 & 23.70 & 22.73 & 22.25 & 23.38 & 24.23 \\
\hline CV (\%) & - & \multicolumn{6}{|c|}{17.18} \\
\hline
\end{tabular}

ns - not significant; Sun - pre-drying in the sun; Salt - salt at the top of silage; CV - coefficient of variation. 
that corn and sorghum silages are more deteriorated by yeasts and filamentous fungi and this causes an increase in temperature.

\section{Conclusions}

Tifton 85 bermudagrass silages present good aerobic stability, and when enriched with corn grits or soybean hulls yeasts start to grow three days after silos are opened. After the fermentation process, populations of lactic bacteria and clostridium increase. Clostridium population should be further studied in experiments with tropical grasses.

\section{References}

ANJOS, J.R.N.; CHARCHAR, M.J.A.; ANJOS, S.S.N. et al. Phoma sp (sect. Peynorellaea), como agente etiológico da mancha foliar de Paspalum atratum no Brasil. Fitopatologia Brasileira, v.30, n.1, p.72-74, 2005.

BARNETT, H.L.; HUNTER, B.B. Illustrated genera of imperfect fungi. New York: Macmillan Publishing Company, 1987. 218p.

BERGER, L.L.; BOLSEN, K.K. Sealing strategies for bunker silos and drive-over piles. In: Proc. Silage for dairy farms: Growing, harvesting, storing, and feeding. NRAES Publ. 181. Ithaca, NY, 2006. p.266-283.

BERNARDES, T.F. Controle da deterioração aeróbia de silagens. 2006. 103f. Tese (Doutorado em Zootecnia) - Universidade Estadual Paulista "Júlio de Mesquita Filho"/Faculdade de Ciências Agrárias e Veterniárias, Jaboticabal.

BERNARDES, T.F.; REIS, R.A.; MOREIRA, A.L. et al. Fermentative and microbiological profile of Marandu palisadegrass ensiled with citrus pulp pellets. Scientia Agricola, v.62, n.3, p.214-220, 2005.

BRAVO-MARTINS, C.E.C.; CARNEIRO, H.; CASTRO GOMES, R.J. et al.Chemical and microbiological evaluation of ensiled sugar cane with different additives. Brazilian Journal Microbiology, v.3, n.37, p.499-504, 2006.

CARMICHAEL, J.W.; KENDRICK, W.B.; CONNERS, I.L. et al. Genera of Hyphomycetes. Manitoba: HignellPrinting, 1980. 386p.

CASTRO, F.G.F.; NUSSIO, L.G.; HADDAD, C.M. et al. Perfil microbiológico, parâmetros físicos e estabilidade aeróbia de silagens de capim-tifton 85 (Cynodon sp.) confeccionadas com distintas concentrações de matéria seca e aplicação de aditivos. Revista Brasileira de Zootecnia, v.35, n.2, p.358-371, 2006.

CHERNEY, J.H.; CHERNEY, D.J.R. Assessing silage quality. In: BUXTON, D.R.; MUCK, R.; HARRISON, J. (Eds.) Silage science and technology. Madison, 2003. p.141-198.

DRIEHUIS, F.; OUDE ELFERINK, W.H.; Van WIKSELAAR, P.G. Fermentation characteristics and aerobic stability of grass silage inoculant with Lactobacillus buchneri, with or without homofermentative lactic acid bacteria. Grass and Forage Science, v.56, n.4, p.330-343, 2001.

EMPRESA BRASILEIRA DE PESQUISA AGROPECUÁRIA EMBRAPA. Sistema brasileiro de classificação de solos. Brasília, 2006. p.412.

FERNANDEZ, M.R. Manual para laboratório de fitopatologia. Passo Fundo: EMBRAPA-CNPT, 1993. 128p.
GUARRO, J.; GENÉ, J.; STCHIGEL, A.M. Developments in fungal taxonomy. Clinical Microbiology Reviews, v.12, n.3, p.454-500, 1999.

INSTITUTO AGRONÔMICO DO PARANÁ - IAPAR. Cartas climáticas do Paraná. 2006. Available at: <http://200.201.27.14/ Site/Sma/Cartas_Climaticas/Classificação_Climaticas.htm>. Accessed on: Sept. 3, 2011.

JOBIM, C.C.; REIS, R.A.; SCHOKEN-ITURRINO, R.P. et al. Desenvolvimento de microorganismos durante a utilização de silagens de grãos úmidos de milho e de espigas de milho sem brácteas. Acta Scientiarum, v.21, n.3, p.671-676, 1999.

JONSSON, A.; PAHLOW, G. Systematic classification and biochemical characterization of yeast growing in grass silage inoculed with Lactobacillus culture. Animal Research and Devevelopment, v.20, p.7-22, 1984.

LIMA, J.A.; EVANGELISTA, A.R.; ABREU, J.G. et al. Silagem de cana-de-açúcar (Saccharum officinarum L.) enriquecida com uréia ou farelo de soja. In: REUNIÃO ANUAL DA SOCIEDADE BRASILEIRA DE ZOOTECNIA, 39., 2002, Recife. Anais... Recife, 2002. (CD-ROM).

LINDGREN, S. Can HACCP principles be applied for silage safety In: INTERNATIONAL SILAGE CONFERENCE, 7., 1999, Uppsala. Proceedings... Uppsala: Swedish University of Agricultural Science, 1999. p.51-66.

McDONALD, P.; HENDERSON, A.R.; HERON, S.J.E. The biochemistry of silage. 2.ed. Marlow: Chalcombe Publications, 1991. 340p.

MENEZES, M.; SILVA-HANLIN, D.M.W. Guia prático para fungos fitopatogênicos. Recife: UFRPE, 1997. 106p.

MEESKE, R.; BASSON, H.M.; CRUYWAGEN, C.W. The effect of a lactic acid bacterial inoculants with enzymes on the fermentation dynamics, intake and digestibility of Digitaria eriantha silage. Animal Feed Science and Technology, v.81, n.3/4, p.237-248, 1999.

MUCK, R.E. Effects of corn silage inoculants on aerobic stability. Transactions of the ASAE, v.47, p.1011-1016, 2004.

PAHLOW, G; MUCK, R.E.; DRIEHUIS, F. et al. Microbiology of ensiling. In: BUXTON, D.R.; MUCK, R.E.; HARRISON, J.H. (Eds.) Silage science and technology. 1.ed. Madison: American Society of Agronomy, 2003. p.31-94.

PEREIRA, O.D.; ROCHA, K.D.; FERREIRA, C.L.L.F. Composição química, caracterização e quantificação da população de microorganismos em capim-elefante cv. Cameroon (Pennisetum purpureum, Schum) e suas silagens. Revista Brasileira de Zootecnia, v.36, n.6, p.1742-1750, 2007.

PEREIRA, O.G.; SANTOS, E.M. Microbiologia e o processo de fermentação em silagens. In: SIMPOSIO SOBRE MANEJO ESTRATÉGICO DA PASTAGEM, 3., 2006, Viçosa, MG. Anais... Viçosa, MG: UFV, 2006. p.393-429.

SAMSON, R.A.; HOEKSTRA, E.S.; FRISVAD, J.C. et al. Introduction to food-borne fungi. Baarn: CBS, 1995. 322p.

SILVA, N.; JUNQUEIRA, V.C.A.; SILVEIRA, N.F.A. Manual de métodos de análise de alimentos. São Paulo: Livraria Varela, 1997. 295p.

SCHOCKEN-ITURRINO, R.P.; REIS, R.A.; COAN, R.M. et al. Alterações químicas e microbiológicas nas silagens de capimtifton 85 após abertura dos silos. Revista Brasileira de Zootecnia, v.34, n.2, p.464-471, 2005.

TOSI, P.; MATTOS, W.R.S.; TOSI, H. et al. Avaliação do capimelefante (Pennisetum purpureum Scum.) Cultivar Taiwan A-148, ensilado com diferentes técnicas de redução de umidade. Revista Brasileira de Zootecnia, v.28, n.5, p.947-954, 1999.

WOOLFORD, M.K. The silage fermentation. New York: Marcela Dekker, 1984. 350p.

WOOLFORD, M.K. The detrimental effect of air on silage. Journal of Applied Bacteriology, v.68, p.101-116, 1990. 